\title{
プラスチック用疲学試験機の試作*
}

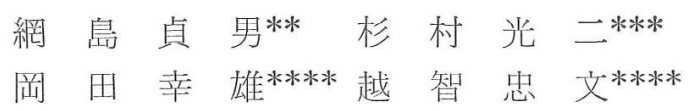

\section{A Newly Designed Dynamic Fatigue Testing Machine for Plastics}

by

\author{
Sadao Amijima, Koji Sugimura \\ (Faculty of Engineering, Doshisha University, Kyoto) \\ Yukio OKada and Tadafumi Ochi \\ (Kisha Seizo Kaisha, Ltd. Osaka)
}

\begin{abstract}
A new fatigue testing machine of constant load type has been designed for the purpose of investigating the dynamic fatigue which is characteristic of plastic materials, because the plastics reinforced by glass fiber (so-called FRP) is practically used for structural members inplace of metals.

Fig. 1 shows the general view of this machine which has the capacity of $1000 \mathrm{~kg}$ and several merits described as follows.

(1) Regardless the change in the rigidity of the test piece during the fatigue test, the dynamic load that acts on the test piece is still kept constant.

(2) Three testing speeds can be selected.

(3) Variation of the dynamic load and the testing speed is negligibly small.

As the result of many fundamental tests it is confirmed that the machine operates as has previously been expected.

(Received Jan. 21, 1967)
\end{abstract}

\section{1 緒言}

最近のプラスチック材料の開発はめざましいものが あり，強度部材としても，すでにガラス繊維布あるい はガラスフィラメントなどの強化材をプラスチック基 材と組み合わせた，いわゆる，強化プラスチック (FRP) 力゙金属材料に代わって奏用化されつつあること は周知のとおりである。これらプラスチック材料の基 本的な特性について究明すべき事項は数多くあるが, 強度部材に使用するためには，その疼労強度に関して 充分に研究する必要があり，すでに若干の疼労試験結 果か溌表されている。しかしながら金属材料に比べて 剛性が低く，しか子試験中における剛性の変化が著し いうえ，荷重とひずみの関係についてはヒステリシス の影響が大きいので，徒来の金属材料用疲労試験機を プラスチック材料の疲労試験に利用するととは䛊まっ た試験結果をまねく醬念がある。

今回試作した試験機は而久性，精度など従来から必 要とされた諸条件を具有するとともに，下記の条件を 满足するものを目的として計画したものであり，Fig. 1 亿その外観を示す.

\footnotetext{
* 原稿受理 沼和 42 年 1 月 21 日

* 正会員 同志社大学工学部 京都市上京区今出川通鳥丸東

**** 同志社大学工学部 京都市上京区今出川通鳥丸東

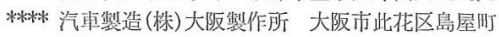

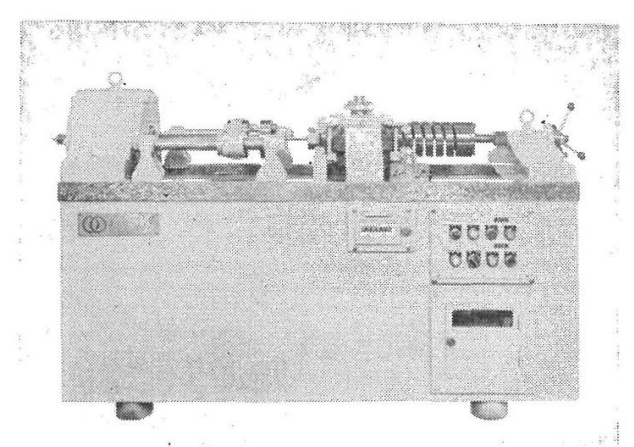

Fig. 1. General view of the machine.

（1）試験中に試験片の岡性がかなり大愊に变化して も試験片には常に一定の繰返し荷重を加えるととがで きる。

（2）繰返し速さを 3 段階に切り替えるととができる。

（3）最低の繰返し速さは比較的低速にする。

（4）運転中の繰返し荷重わよび繰返し速さの変動率 を極小にする.

（5）試験中に試験片の長さが変化しても試験片には 一定の平均街重を加えるととができる。

（6）試験中試験片の変形量を一定にするように平均 
荷重を制御するととができる。

（7）試験片の変形量を時間に対して記録するてとが できる。

（8）周囲温度を低温から高温まで連続的に変化する ととができる。

（9）引張圧縮試験のほか力ねじりおよび曲げ試験を 行なうことができる。

以上の各項目のうちさしあたり(1)項から(4)項を満足 する試験機を製作し，荷重の検定ならびに基本的な実 用試験の結果期待どおりの性能を確認することができ た.引引き続き(5)項から(9)項を満足するための各種の付 属装置を目下試作中であり，その結果は後日発表する 予定である，以下に本試験機の概要と二，三の試験結 果について報告する。

\section{2 試作した試験機}

\section{$2 \cdot 1$ 試験機の主要目}

最大荷重（繰返し荷重と平均荷重の和）

$\begin{array}{ll}\text { 最大繰返し荷重 } & \pm 500 \mathrm{~kg} \\ \text { 最大平均荷重 } & +500 \mathrm{~kg}, \\ \text { 繰返し速さ } & 1000,1440, \\ \text { 最大振幅 } & \pm 5 \mathrm{~mm} \\ \text { チャック間隔 } & 0 \sim 380 \mathrm{~mm} \\ \text { 最大幅 } & \text { 約 } 0.5 \mathrm{~m} \\ \text { 最大高さ } & \text { 約 } 1.0 \mathrm{~m} \\ \text { 全長 } & \text { 約 } 1.8 \mathrm{~m}\end{array}$

電動機

繰返し荷重用 $0.75 \mathrm{~kW} 3$ 相超反作用電動機

静荷重用 $0.2 \mathrm{~kW} 3$ 相かで形誘導電動機 重量

\section{$2 \cdot 2$ 試験機の構造}

Fig. 2 において(1)はベッドであり，高い剛性を有す るとともに防振ゴム(2)と組み合わせて基礎へ伝達する 振動を吸収しうるに充分な重量を有している。図の中 央部の6は偏心重鍾を回転するととにより繰返し荷重 を発生する機械式発振機であり，繰返し荷重用電動機 (3)（この電動機は同期電動機の一種であるが直流励磁 は不要である) により変速機(4)からマイタ歯車(5)へ伝 達された動力は，たわみ軸を介してての発振機を駆動 している. 繰返し速さの変換は変速機(4)のハンドルを 操作して行なうことができる。なお，発振機は摩擦に よる振動の減衰を防止し，また，長期使用時も遊隙の 発生などによる荷重波形の乱れを皆無にするため，平 板ばね接手を介してベッドより支持されている，繰返 し荷重設定円板(7)には繰返し荷重値が最小 $0.7 \mathrm{~kg}$ 単位 で目盛られている。静荷重ばね8は共振ばねとしての 役めも兼ねているため, 荷重一たわみ特性が张压縮 両方向に対し厳密に線形であるととが望ましいので， 円筒素材より機械加工したばねを使用している。9は 静荷重を加えるためのねじ棒とハンドル装置である. 調整質量(10は繰返し速さを変換した場合に，その速 さが発振機を含む振動部の質量と静荷重ばね8とで形 成する振動系の固有振動数に一致するように調整する ためのものである，ての調整を行なうことにより，試 験中に試験片の唰性が变化しても繰返し荷重の変動は ほとんどなくなる。(111は試験片，(12)は摺動案内装置， (13)は運転中に試験片が伸縮しても静荷重を一定に制御 するためのジャッキ装置である。この装置は静荷重制 御用電動機(14)より䟓動される。操作盤(15)運転および 停止に必要な押ボタンおよび表示灯を供えている。継

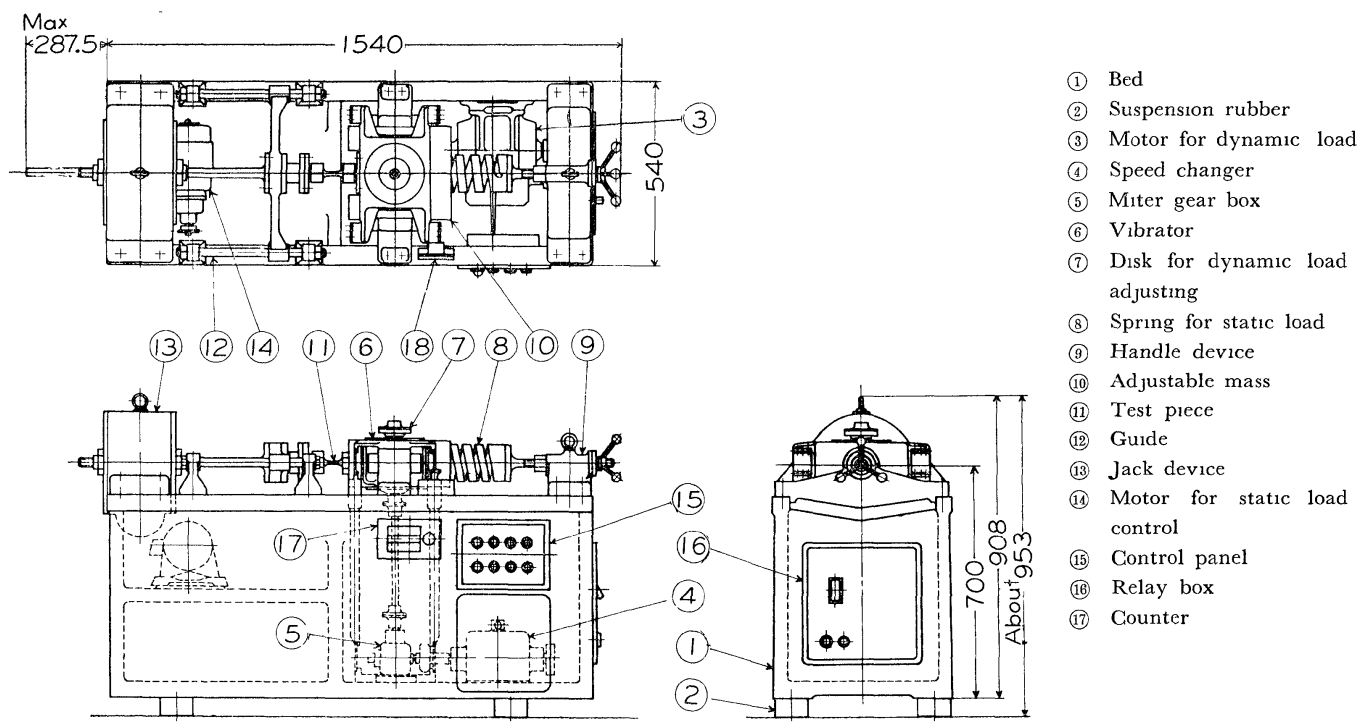

Fig. 2. The construction of the machine. 
電器盤16は操作盤と同じくベッドに内蔵されており, 発振機の振幅が規定值以上になったり，あるいは試験 片が破断したときは自動的に試験機を停止するに要す る電気装置を内蔵している。19は積算繰返し回数を $10^{8}$ 回まで表示できる積算カウンタである.

\section{2・3 試験片に加えられる繰返し荷重の解析}

本試験機の振動系は防振ゴム，ベッド，静荷重ばね， 発振機および試験片より構成され，その配置は Fig. 3 に示すとおりである。

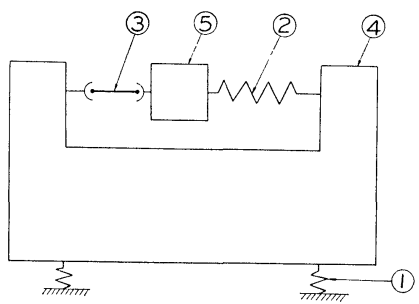

(1) Suspension rubber (2) Spring for static load

(3) Test piece (4) Bed (5) Vibrator

Fig. 3. The schematic view of vibration system.

Fig. 3 の振動系において

防振ゴムのせん断ばね定数 $k_{1}$

静荷重ばねのばね定数 $k_{2}$

試験片のばね定数 $k_{3}$

ベッドの質量 $m_{1}$

発振機の質量 $m_{2}$

ベッドの振幅 $x_{1}$

発振機の振幅 $x_{2}$

発振機の加振力 $f(t)=F_{0} \sin \omega t$

ただし， $F_{0}$ は加振力の最大値， $\omega$ は発振角周波数，

$t$ は時間である。

とすれば振動系は Fig. 4 と等価になり，その運動方 程式は(1)式で示される。

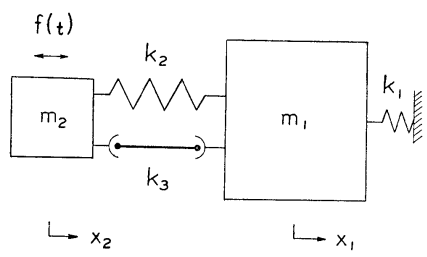

Fig. 4. Equivalent vibration system of the machine.

$$
\left.\begin{array}{l}
m_{2} \frac{d^{2} x_{2}}{d t^{2}}+\left(k_{2}+k_{3}\right)\left(x_{2}-x_{1}\right)=F_{0} \sin \omega t \\
m_{1} \frac{d^{2} x_{1}}{d t^{2}}+k_{1} x_{1}-\left(k_{2}+k_{3}\right)\left(x_{2}-x_{1}\right)=0
\end{array}\right\}
$$

(1)式の解を求めれば振幅 $x_{1}, x_{2}$ はそれぞれ次のように なる。

$$
\begin{aligned}
x_{1}= & \frac{F_{0}\left(k_{1}+k_{2}+k_{3}-m_{1} \omega^{2}\right)}{\left(k_{2}+k_{3}-m_{2} \omega^{2}\right)\left(k_{1}+k_{2}+k_{3}-m_{1} \omega^{2}\right)-\left(k_{2}+k_{3}\right)^{2}} \\
x_{2}= & \frac{F_{0}\left(k_{2}+k_{3}\right)}{\left(k_{2}+k_{3}-m_{2} \omega^{2}\right)\left(k_{1}+k_{2}+k_{3}-m_{1} \omega^{2}\right)-\left(k_{2}+k_{3}\right)^{2}}, \\
& \sin \omega t
\end{aligned}
$$

したがって，試験片に加えられる繰返し荷重の大きさ $f_{0}$ は

$$
\begin{aligned}
f_{0}= & k_{3}\left(x_{2}-x_{1}\right) \\
= & \frac{-F_{0} k_{3}\left(k_{1}-m_{1} \omega^{2}\right)}{\left(k_{2}+k_{3}-m_{2} \omega^{2}\right)\left(k_{1}+k_{2}+k_{3}-m_{1} \omega^{2}\right)-\left(k_{2}+k_{3}\right)^{2}} \\
& \sin \omega t
\end{aligned}
$$

試験機の繰返し速さは静荷重ばねと発振機の質量て 構成される固有振動数に一致させるため(4)式において $\omega^{2}=k_{2} / m_{2}$ とおけば,

$$
f_{0}=\frac{-F_{0}}{1-\frac{1+\frac{k_{2}}{k_{3}}}{\frac{k_{1}}{k_{2}}-\frac{m_{1}}{m_{2}}}} \sin \omega t
$$

(5) 式において $k_{1} \rightarrow \infty$ または $m_{1} / m_{2} \rightarrow \infty$ のときは $f_{0}$ $=-F_{0} \sin \omega t$ となり, 発振機より発生する加振力はそ のまま試験片に繰返し荷重として加えられ, 最も理想 的な試験機となるととがわかる。しかし，ての条件を 満足するためには大がかりな基礎工事を必要とする。

今回試作したものは(5)式の各定数がそれぞれ次の值 である。

防振ゴムのせん断ばね定数 $k_{1}=27.2 \mathrm{~kg} / \mathrm{mm}$ 静荷重ばねのばね定数 $k_{2}=51 \mathrm{~kg} / \mathrm{mm}$ ベッドの重量 $w_{1}=1500 \mathrm{~kg}$ 発振機の重量 $w_{2}=20 \mathrm{~kg}$ これに基づいて試験中に試験片の剛性が 7/8 (FRP で はこの変化を生じた場合を破断とみなす)，1/2および

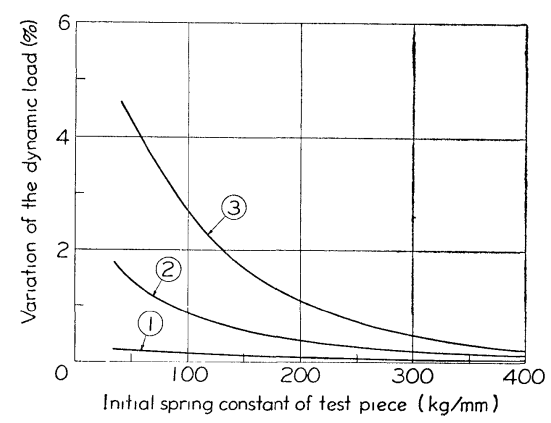

The curves (1) (2) and (3) show the cases when the rigidity of test prece change to $7 / 8,1 / 2$ and $1 / 4$ of 1 ts initial value respectively.

Fig. 5. Theoretical dynamic load variation curve. 
$1 / 4$ 亿変化した場合繰返し荷重がいかほど変動するか を数值計算で求めたのが Fig. 5 である。

Fig. 5 より，試験片のばね定数が低くても刪性の变 化が $1 / 2$ 以下であれば荷重変動は $2 \%$ 以下となり実用 上問題にならないことがわかる。

\section{$3 \cdot 1$ 繰返し応力波形}

\section{3 試験結果亡考察}

引張圧縮試験片に抵抗線ひずみ計を張り電磁オシロ で測定した繰返し応力波形は Fig. 6 のとおりであり， 良好な正弦波であることが確認された。

Dynamic load $\pm 370 \mathrm{~kg}$, speed $1800 \mathrm{cpm}$

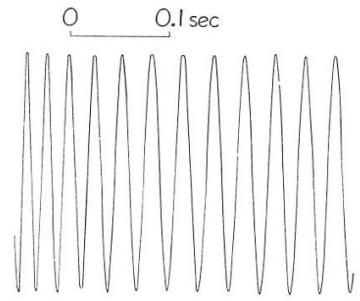

Fig. 6. The figure shows the shape of wave form of the dynamic load.

\section{$3 \cdot 2$ 繰返し速さの変動}

本試験機の加振力は偏心重鉡の回転により発生する 遠心力を利用しているので, 繰返し速さが変動すれば 繰返し荷重はその二乘に比例して変動する。.そこで, 商用周波数電源での繰返し速さの変動状洗を 3 日問に わたり，デイジタル回軾計で測定した，Table I にそ の結果京す。この結果, 繰返し速さの変動率は 0.2 \%以下で，それによる繰返し蔺重の変動率は $0.4 \%$ に も達しないととがわかる。

\section{$\mathbf{3} \cdot \mathbf{3}$ 繰返し荷重の変動}

3・1項で応力波形を测定したのと同方法で, 電磁才 シロの送り速度を遅くして繰返し荷重を測定した結果 花 Fig. 7 に示す。との結果，繰返し荷重の変動率は きわめて低いととがわかる。

\section{3・4 実用試験}

Fig. 8, 9 および 10 は本試験機を用いて行なった実 用試験の結果を線図にまともたものである。Fig. 11は この試験に使用した試験片の形状を示す。
Fig. 8 は比較的弾性係数の低いポリカーボネイト樹 脂およびポリエステル樹脂の両振弓張圧縮瘦労試験結

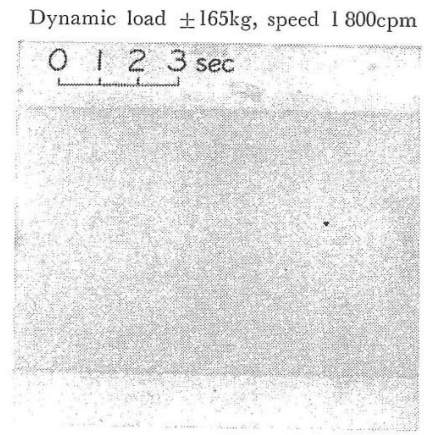

Fig. 7. The figure shows the change of the dynamic load amplitude.

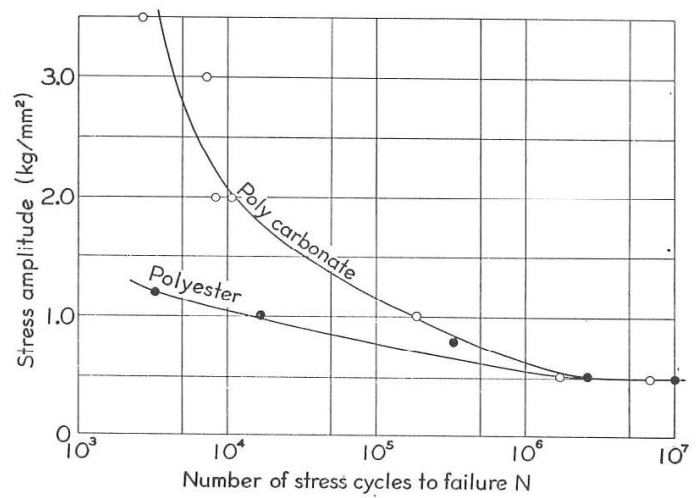

Fig. 8. $S-N$ curve of polycarbonate and polyester.

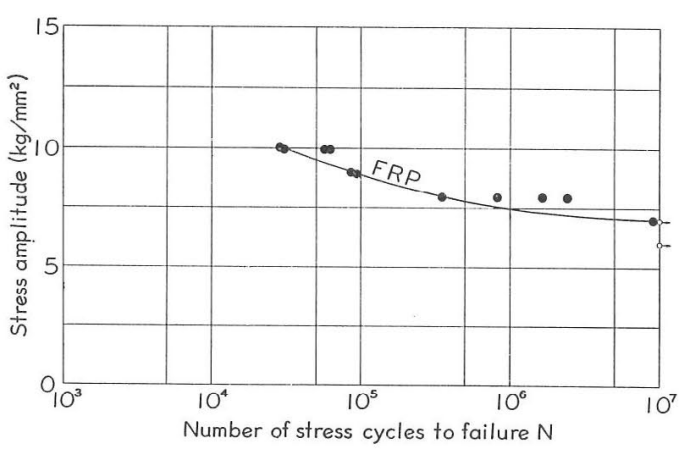

Fig. 9. $S-N$ curve of FRP.

Table I. The test value of the testing speed.

\begin{tabular}{|c|c|c|c|c|c|c|c|c|c|c|}
\hline \multirow{2}{*}{\multicolumn{2}{|c|}{ Item }} & \multicolumn{3}{|c|}{ First day } & \multicolumn{3}{|c|}{ Second day } & \multicolumn{3}{|c|}{ Third day } \\
\hline & & 1000 & 1440 & 1800 & 1000 & 1440 & 1800 & 1000 & 1440 & 1800 \\
\hline Test value & No.1 & 1000.54 & 1440.26 & 1800.27 & 1000.81 & 1440.26 & 1799.71 & 1000.27 & 1440.80 & 1801.63 \\
\hline " & No.2 & 1000.81 & 1440.80 & 1800.00 & 1001.09 & 1441.35 & 1799.71 & 1000.81 & 1441.35 & 1801.90 \\
\hline " & No.3 & 1000.54 & 1441.62 & 1800.27 & 1000.81 & 1440.26 & 1800.54 & 1001.36 & 1440.53 & 1802.98 \\
\hline " & No.4 & 1000.81 & 1440.53 & 1800.27 & 1000.81 & 1440.00 & 1800.00 & 1001.36 & 1440.80 & 1801.35 \\
\hline
\end{tabular}




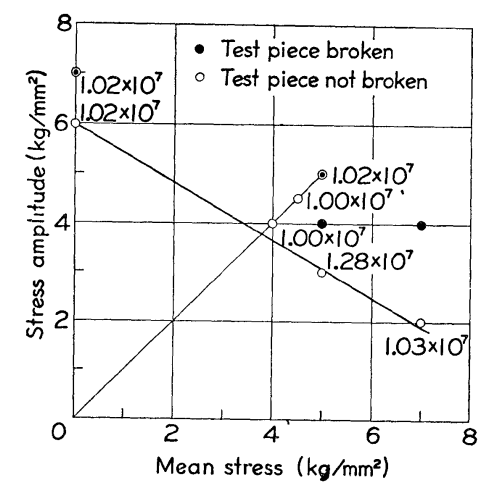

Fig. 10. Fatigue limit curve of FRP.

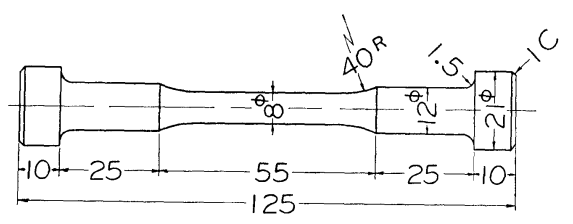

Fig. 11. Test piece (mm).

果を $S-N$ 曲線にまとめたものである。いずれも引張 強度の弱い材料であるにもかかわらず破断点のばらつ きが少ないととは，試験片取付時に異常な初期応力が 発生せず，しかも運転中の繰返し応力も一定值を保持 したものとみなされる。

Fig. 9 は FRP（基材はポリエステル，強化材は無 アルカリガラス，ボラン処理品で，ガラス含有率は72
\%)の両振引張圧縮疲労試験結果を示す。乙の場合も 破断点のばらつきは少ない。

Fig. 10 は FRP の $10^{7}$ 回疲労限度線図である。一 般の金属材料に比べ線図の傾斜がいぶん急こう配で あるように思われる。このととはFRP のほうが金属 材料よりも疲学強度に対して静荷重の影響を大きく受 けるものと推定される。

\section{4 結言}

プラスチック材料用疲学試験機として荷重一定, 横 形疲学試験機を試作したとの試験機は複雑な自動制 御装置を要せずして運転中亿試験片の剛性が変化して も試験片に一定の繰返し荷重を加えるととができるも のである，製作後性能を確認するための検定ならびに 基本的な実用試験を実施したが，いずれも期待どおり の結果を得るととができた，今後本試験機を活用して 種々の疲学試験を実施すれば，プラスチック材料の振 動疲学特性に関して貴重な資料を得ることができると 思われる。なお，引き続き本試験機の付属装置として 平面曲げ装置, ねじり装置ならびに高温低温両用の恒 温試験装置を試作中であり，その結果は後日発表する 予定である。

終わりに，本研究は文部省より研究費（昭和40年度 総合研究費) の補助を受けて行なわれたてとを付記す るとともに，試験片の材料を提供いただいた大日本イ ンキ化学工業株式会社ならびに本研究にで協力いただ いた関係各位に感謝の意を表する。 